\title{
Effect of Three Harvest Intervals on the Yield and Protein Content of Ten Brachiarias ${ }^{1}$
}

\author{
A. Sotomayor-Rios, J. Rodriguez-Garcia, and J. Vélez-Santiago ${ }^{2}$
}

\section{ABSTRACT}

Ten Brachiarias were evaluated during an 18-month period at various harvest intervals at the Corozal Substation for yields of green forage (GF), dry forage (DF), and crude protein (CP), and for contents of (CP) and dry matter (DM).

At the 30-day harvest interval, the most productive introduction was Brachiaria humidicola (P.I. 299497), with 119,567 and $22,548 \mathrm{~kg} / \mathrm{ha} /$ year of GF and DF, respectively. Para grass (B. mutica) and B. ruziziensis (P.I. 247404) had the highest DM content, $22.5 \%$. Para grass also had the highest CP yield, $2,961 \mathrm{~kg} / \mathrm{ha} /$ year.

At the 45-day harvest interval, B. humidicola (P.I. 299497) had the highest GF yield, $160,459 \mathrm{~kg} / \mathrm{ha}$ /year, while para grass had the highest DM content, $22.5 \%$. Para grass was the highest DF yielder, with $31,338 \mathrm{~kg} / \mathrm{ha} /$ year, and B. humidicola (P.I. 299497) was the highest CP yielder, with $3,787 \mathrm{~kg} / \mathrm{ha} /$ year.

At the 60-day harvest interval, B. humidicola (P.I. 299497) was the highest GF yielder, with $146,318 \mathrm{~kg} / \mathrm{ha} /$ year, while para grass had the highest DM content and DF and CP yields, $25.9 \%, 36,946 \mathrm{~kg} / \mathrm{ha} /$ year, and $3,264 \mathrm{~kg} / \mathrm{ha} /$ year, respectively.

The GF and DF yields increased with length of the harvest interval. The DM contents, however, were similar at the 30- and 45-day intervals and higher at the 60-day interval. The CP yields increased from $2,651 \mathrm{~kg} / \mathrm{ha} /$ year at the 30 -day harvest interval to $2,912 \mathrm{~kg} / \mathrm{ha} /$ year at the 60 -day harvest interval.

The DF and CP yields of B. humidicola (P.I. 299497), para grass, signal grass (B. brizantha, P.R. P.I. 1525), and others were excellent and compared favorably with those of the recognized top-yielding grasses in Puerto Rico.

\section{INTRODUCTION}

In 1977, Bogdan (1) reviewed knowledge of the best-known Brachiaria species ( $B$. brizantha, B. dura, B. humidicola, B. miliiformis, $B$. mutica, $B$. radicans, and $B$. ruziziensis). He covered plant description, areas of adaptation, method of propagation, ability to mix with legumes, nutritive value, chromosome number, and more. Loch (3), also in 1977, reviewed knowledge of Brachiaria decumbens (signal grass), with particular reference to Australia. His review indicated that signal grass is a highyielding stoloniferous grass adapted to a wide range of well-drained soils in the humid tropics. Loch further indicated that signal grass, having no major pest and disease problems, is generally better suited to such areas than pangola grass (Digitaria decumbens), except where flooding or poor drainage prevails. At Gurabo, Puerto Rico, Sotomayor-Ríos et al. (7)

\footnotetext{
${ }^{1}$ Manuscript submitted to Editorial Board February 4, 1980.

${ }^{2}$ Research Geneticist, Mayagüez Institute of Tropical Agriculture, Agricultural Research, Science and Education Administration, U.S. Department of Agriculture, Mayagüez, P.R. 00708; Assistant Agronomist, and Associate Agronomist, respectively, Corozal Substation, Agricultural Experiment Station, Mayagüez Campus, University of Puerto Rico, Río Piedras, P.R. 00928.
} 
compared another species of signal grass (Brachiaria brizantha, P.R. P.I. 1525) with guinea grass (Panicum maximum) at various cutting intervals. Both grasses were harvested about every 60 days, and both produced about 29 tons of DF per hectare per year. The same signal grass (P.R. P.I. 1525) was compared with pangola grass and giant pangola grass (Digitaria valida) under grazing management at Corozal, Puerto Rico, for 613 days (4). There were no significant differences between signal grass and pangola grass in yield of total digestible nutrients and in carrying capacity, and both were significantly superior to giant pangola grass,

Other Brachiaria introductions have been tested in Puerto Rico at various cutting intervals (5-9). Among the species reported to be most productive are B. humidicola (P.I. 299497), B. brizantha (P.I. 255346), B. decumbens (P.I. 210724) and Congo grass, B. ruziziensis (P.I. 247404) $(8-10)$.

In Puerto Rico, as in many other tropical countries, para grass ( $B$. mutica) is a well-known species that provides abundant forage of acceptable quality. This grass is predominant in many pastures in Puerto Rico, and under poor management it can smother other pastures. Under good grazing management, this grass yields much less than other well-known forages. According to Caro-Costa et al. (2), beef production on para grass pastures at Orocovis, Puerto Rico, was only $2 / 3$ of that obtained from pangola grass, guinea grass, or napier grass (Pennisetum purpureum). According to Whitney et al. (10), there are extensive areas of para grass that should be replanted with more productive pastures, since under grazing management para grass is less palatable to cattle than other species.

This research was designed to study the effect of three harvest intervals on the yield and protein content of 10 Brachiarias, including para grass and signal grass, grown in the humid mountain region of Puerto Rico.

\section{MATERIALS AND METHODS}

The experiment was conducted for 18 months at the Corozal Substation at about $214 \mathrm{~m}$ elevation in the humid mountainous region of Puerto Rico. The soil is a Corozal clay, one of the Aquic Tropudults.

The Brachiaria introductions used are shown in table 1.

The 10 grasses were evaluated in a randomized split-plot design with four replications. Species were the main plots, and harvest intervals of 30,45 , and 60 days were the subplots. The main plots were $27.87 \mathrm{~m}^{2}$; the subplots, $9.27 \mathrm{~m}^{2}$.

A 15-5-10 fertilizer was used at 3,360 kg/ha yearly in 6,8 , and 12 equal applications corresponding to the harvest interval tested. All grasses were sprigged by hand and cut at about $8 \mathrm{~cm}$ from the ground. The forage was 
weighed, and samples were taken, dried at $53.6^{\circ} \mathrm{C}$, ground in a mill, and passed through a $1-\mathrm{mm}$ screen. Dry matter was determined in all samples and analyzed for CP. Total $\mathrm{N}$ was determined with a Technicon. Auto Analyzer $^{3}$, and CP was calculated as $\mathrm{N} \times 6.25$. Data for GF, DF, DM, and DP were subject to analysis of variance, and tested with Duncan's multiple range test for significance and differences.

\section{RESULTS AND DISCUSSION}

Table 2 shows data on yield of the 10 grasses at the 30-, 45-, and 60-day harvest intervals during an 18-month period at Corozal.

Brachiaria humidicola (P.I. 299497) had the highest GF yield at the 30-day interval, although its yield was not significantly different from

TAble 1.-Ten Brachiarias evaluated at Corozal, Puerto Rico

\begin{tabular}{lccl}
\hline \multirow{2}{*}{ Species } & \multicolumn{3}{c}{ Plant introduction number } \\
\cline { 2 - 4 } & USDA P.I. & P.R. P.I. & \multicolumn{1}{c}{ Common name } \\
\hline Brachiaria brizantha & - & 1525 & Signal grass \\
B. mutica & 299499 & 6451 & Tanner grass \\
B. ruziziensis & 247404 & 5366 & Congo grass \\
B. ruziziensis & 344764 & 11718 & - \\
B. humidicola & 299497 & 9626 & - \\
B. ruziziensis & 338221 & 11716 & - \\
B. ruziziensis & 338220 & 11544 & - \\
B. ruziziensis & 347236 & - & - \\
B. ruziziensis & 347237 & - & C.S.I.R.O. ${ }^{3} 26964$ \\
B. mutica & - & - & Para grass \\
\hline
\end{tabular}

${ }^{1}$ United States Department of Agriculture plant introduction number.

${ }^{2}$ University of Puerto Rico Agricultural Experiment Station plant introduction number.

${ }^{3}$ Council for Scientific and Industrial Research Organization.

those of signal grass (B. brizantha) and B. ruziziensis, P.I. 347236. Yields ranged from 119,567 to $93,005 \mathrm{~kg} / \mathrm{ha} /$ year; tanner grass (B. mutica, P.I. 299499) produced the lowest yield. Dry matter content was similar among the 10 Brachiarias. Brachiaria ruziziensis, P.I. 247404 and the unnumbered para grass had the highest values (22.5\%), whereas $B$. humidicola (P.I. 299497) had the lowest (21.0\%). Dry forage yields ranged from 22,548 to $16,882 \mathrm{~kg} / \mathrm{ha} / \mathrm{yr}$. The highest DF producer was B. humidicola (P.I. 299497), which significantly outyielded B. ruziziensis, P.I.'s 347237 and 344764 and $B$. mutica, P.I. 299499. Crude protein yields of the grass were similar, except that the unnumbered para grass (B. mutica) significantly outyielded B. ruziziensis, P.I.'s 338221 and 344764.

${ }^{3}$ Trade names in this publication are used only to provide specific information. Mention of a trade name does not constitute a warranty of equipment or materials by the Agricultural Experiment Station of the University of Puerto Rico, nor is this mention a statement of preference over other equipment or materials. 
TABLE 2.-Effect of harvest frequency on the yield of forage and crude protein and the dry-matter content of 10 Brachiarias grown at Corozal, P.R., during an 18-month period

\begin{tabular}{|c|c|c|c|c|c|}
\hline Species & $\begin{array}{l}\text { USDA P.I. } \\
\text { number }\end{array}$ & $\begin{array}{l}\text { Green-forage } \\
\text { yield }\end{array}$ & $\begin{array}{l}\text { Dry matter } \\
\text { content }\end{array}$ & Dry forage yield & $\begin{array}{c}\text { Crude prot } \\
\text { yield }\end{array}$ \\
\hline & & $K g / h a / y r$ & $\%$ & $\mathrm{Kg} / \mathrm{ha} / \mathrm{yr}$ & $\mathrm{Kg} / \mathrm{ha} / \mathrm{s}$ \\
\hline \multicolumn{6}{|c|}{ 30-day harvest period } \\
\hline \multicolumn{6}{|l|}{ Brachiaria } \\
\hline humidicola & 299497 & $119,567 \mathrm{a}^{2}$ & $21.0 \mathrm{~b}$ & 22,548 a & $2,882 \mathrm{ab}$ \\
\hline B. brizantha & $1525^{3}$ & $105,834 \mathrm{ab}$ & $22.1 \mathrm{ab}$ & $21,165 a b$ & $2,783 a b$ \\
\hline B. ruziziensis & 347236 & $104,129 \mathrm{ab}$ & $21.7 \mathrm{ab}$ & 19,724 abc & $2,746 \mathrm{ab}$ \\
\hline B. ruziziensis & 338221 & 99,095 b & $21.8 \mathrm{ab}$ & $18,992 \mathrm{abc}$ & $2,454 \mathrm{~b}$ \\
\hline B. mutica & - & $98,687 \mathrm{~b}$ & $22.5 \mathrm{a}$ & $19,214 \mathrm{abc}$ & 2,961 a \\
\hline B. ruziziensis & 347237 & $97,737 \mathrm{~b}$ & $21.9 \mathrm{ab}$ & 18,394 bc & $2,502 \mathrm{ab}$ \\
\hline B. ruziziensis & 338220 & $96,656 \mathrm{~b}$ & $21.7 \mathrm{ab}$ & $18,663 \mathrm{abc}$ & $2,551 \mathrm{ab}$ \\
\hline B. ruziziensis & 247404 & $94,525 \mathrm{~b}$ & $22.5 \mathrm{a}$ & $19,296 \mathrm{abc}$ & $2,611 \mathrm{ab}$ \\
\hline B. ruziziensis & 344764 & $94,286 \mathrm{~b}$ & $21.5 \mathrm{ab}$ & 17,304 bc & $2,408 \mathrm{~b}$ \\
\hline \multirow[t]{2}{*}{ B. mutica } & 299499 & $93,005 \mathrm{~b}$ & $21.5 \mathrm{ab}$ & $16,882 \mathrm{c}$ & $2,608 \mathrm{ab}$ \\
\hline & $\bar{x}$ & 100,352 & 21.8 & 19,218 & 2,651 \\
\hline
\end{tabular}

\section{5-day harvest period}

\section{Brachiaria humidicola \\ B. mutica \\ B. brizantha \\ B. mutica \\ B. ruziziensis \\ B. ruziziensis \\ B. ruziziensis \\ B. ruziziensis \\ B. ruziziensis \\ B. ruziziensis}

$\begin{array}{rl}299497 & 160,459 \mathrm{a} \\ - & 151,697 \mathrm{a} \\ 1525 & 134,853 \mathrm{~b} \\ 299499 & 123,030 \mathrm{bc} \\ 338221 & 120,808 \mathrm{bc} \\ 347236 & 120,614 \mathrm{bc} \\ 347237 & 119,902 \mathrm{bc} \\ 247404 & 114,583 \mathrm{c} \\ 338220 & 112,906 \mathrm{c} \\ 344764 & 112,652 \mathrm{c} \\ \overline{\mathrm{X}} & 127,150\end{array}$

60-day harvest period

\section{Brachiaria}

$\quad$ humidicala
B. mutica
B. brizantha
B. ruziziensis
B. mutica
B. ruziziensis
B. ruziziensis
B. ruziziensis
B. ruziziensis
B. ruziziensis

$\begin{array}{rl}299497 & 146,318 \mathrm{a} \\ - & 143,908 \mathrm{a} \\ 1525 & 136,553 \mathrm{ab} \\ 347237 & 133,894 \mathrm{abc} \\ 299499 & 132,113 \mathrm{abc} \\ 347236 & 131,960 \mathrm{abc} \\ 338221 & 126,124 \mathrm{bc} \\ 344764 & 124,057 \mathrm{bc} \\ 338220 & 117,879 \mathrm{c} \\ 247404 & 117,463 \mathrm{c}\end{array}$

$\overline{\mathrm{X}} \quad 131,027$

$21.7 \mathrm{e}$
$25.9 \mathrm{a}$
$24.0 \mathrm{~b}$
$22.1 \mathrm{e}$
$23.8 \mathrm{bc}$
$22.8 \mathrm{cde}$
$22.4 \mathrm{de}$
$22.8 \mathrm{cde}$
$23.3 \mathrm{bcd}$
$22.4 \mathrm{de}$

23.1

$\begin{array}{ll}19.8 \text { d } & 30,633 \text { a } \\ 22.5 \text { a } & 31,338 \text { a } \\ 21.9 \text { ab } & 27,597 \mathrm{~b} \\ 20.9 \text { bcd } & 23,361 \mathrm{c} \\ 21.0 \mathrm{bc} & 22,826 \mathrm{c} \\ 20.5 \mathrm{c} & 21,728 \mathrm{c} \\ 20.5 \mathrm{~cd} & 22,133 \mathrm{c} \\ 21.1 \mathrm{bc} & 22,063 \mathrm{c} \\ 21.0 \mathrm{bc} & 21,683 \mathrm{c} \\ 20.9 \mathrm{bcd} & 21,526 \mathrm{c} \\ 21.0 & 24,489\end{array}$

24,489
3,787 a $3,709 \mathrm{ab}$ $3,349 \mathrm{~b}$ $2,744 \mathrm{c}$ $2,691 \mathrm{c}$ $2,678 \mathrm{c}$ $2,482 \mathrm{c}$ $2,544 \mathrm{c}$ $2,580 \mathrm{c}$ $2,558 \mathrm{c}$ 2,912

\footnotetext{
${ }^{1}$ United States Department of Agriculture plant introduction number.

${ }^{2}$ Within each column and harvest period, means in columns followed by one or more letters in common do not differ significantly at $P=0.05$, according to Duncan's multiple range test.

${ }^{3}$ University of Puerto Rico Agricultural Experiment Station plant introduction number.
} 
At the 45-day interval B. humidicola (P.I. 299497) and the unnumbered para grass (B. mutica) exceeded all other grasses in GF yields. Yields ranged from 160,549 to $112,652 \mathrm{~kg} / \mathrm{ha} / \mathrm{yr}$. The unnumbered para grass had the highest DM content, $22.5 \%$, which was significantly different from those of all introductions except signal grass; B. humidicola (P.I. 299497) had the lowest value (19.8\%). The highest DF yielder at the 45day interval was the unnumbered para grass, with $31,338 \mathrm{~kg} / \mathrm{ha} / \mathrm{yr}$. This was significantly different from the yield of all other introductions except that of B. humidicola (P.I. 299497). The highest CP yields were produced by $B$. humidicola $(3,787 \mathrm{~kg} / \mathrm{ha} / \mathrm{yr})$ and the unnumbered para grass $(3,709$ $\mathrm{kg} / \mathrm{ha} / \mathrm{yr})$.

Brachiaria humidicola (P.I. 299497) was the highest GF yielder at the 60-day interval, but its yield was not significantly different from those of the next 5 highest-yielding introductions. Green forage yield ranged from 146,318 to $117,463 \mathrm{~kg} / \mathrm{ha} /$ year; B. ruziziensis, P.I. 247404 had the lowest value. The highest DM content (25.9\%), of the unnumbered para grass, was significantly different from those of the other introductions. Brachiaria humidicola (P.I. 299497) had the lowest value (21.7\%). Average $\mathrm{DM}$ content of the grasses was very similar at the 30 - and 45 -day intervals (21.8 and $21.0 \%$, respectively), but it increased to $23.1 \%$ at the 60 -day interval. Dry forage ranged from 36,946 in the unnumbered para grass to $25,743 \mathrm{~kg} / \mathrm{ha} / \mathrm{yr}$ in B. ruziziensis, P.I. 247404 . The yield of para grass was significantly different from those of the other nine grasses. Crude protein yields of the 10 grasses ranged from 3,087 to $2,439 \mathrm{~kg} / \mathrm{ha} / \mathrm{yr}$. Although the unnumbered para grass had the highest CP yield, it was not significantly different from those of the four next-best cultivars.

On the average, the 10 grasses had DF yields of $19,218,24,489$ and $29,617 \mathrm{~kg} / \mathrm{ha} / \mathrm{yr}$ at the 30,45 , and 60 -day intervals, respectively. These values are higher than those reported by Sotomayor-Rios et al. (8) in Corozal, where nine Brachiarias, nine Digitarias, and stargrass (Cynodon. nlemfuensis var. nlemfuensis) were evaluated at selected cutting intervals during a 2-year period. Dry forage yields of the best Brachiarias in the present trial (the unnumbered para grass, signal grass, and B. humidicola, P.I. 299497) cut at 60-day intervals compared well with that reported by Vicente-Chandler et al. (9) for congo grass (P.I. 247404) cut every 60 days at Corozal, about $33,000 \mathrm{~kg} / \mathrm{ha} / \mathrm{yr}$.

Although the unnumbered para grass was an excellent DF yielder, it might not be as acceptable to farmers as signal grass, pangola grass, or stargrass. Para grass has a low leaf-to-stem ratio, and under grazing management it is very stemmy. This characteristic is probably responsible for the lower weight gain by animals on para grass vs. pangola, guinea or napier grass as was shown by Caro-Costas et al. (2). Signal grass, another top yielder in this experiment and previously tested under grazing management in Puerto Rico (4), is very resistant to trampling, forms a 
thick mat, and recovers relatively fast from grazing. According to RiveraBrenes et al. (4), signal grass is superior to pangola grass because it is not attacked by the yellow aphid, and it is better than guinea grass in preventing soil erosion because it covers the ground completely. Signal grass has a tendency to get burned if it is fertilized while moisture adheres to the dorsal hairs on the leaves. This damage can be prevented by applying the fertilizer when the leaves are dry. Propagation seems to be a limiting factor in this grass.

Under various cutting intervals, some Brachiarias can produce DF yields of more than $30,000 \mathrm{~kg} / \mathrm{ha} / \mathrm{yr}$ when cut at 60 -day intervals. This yield is sufficient to satisfy the forage requirements of about nine $273-\mathrm{kg}$ steers/ha/yr, with a daily DF consumption of $9.08 \mathrm{~kg} /$ day/animal. The selection of the particular Brachiaria to use for further grazing will depend not only on its yield performance under cutting management, but also on its digestibility and resistance to drought and attacks by insects and diseases.

\section{RESUMEN}

En la Subestación de Corozal se evaluaron 10 Brachiarias en diferentes intervalos de corte durante un período de 18 meses. Se midieron los rendimientos de forraje verde (GF), y forraje seco (DF), materia seca (DM) y proteína bruta (CP) a intervalos de corte de 30, 45 y 60 días.

La mejor productora, en términos de GF y FS, en el intervalo de corte de 30 días fue B. humidicola (P.I. 299497), con 119,567 y 22,548 kg/ ha/y año, respectivamente. Los pastos Pará ( $B$. mutica) y B. ruziziensis (P.I. 247404) arrojaron el contenido en DM más alto, 22.5\%. Además, el Pará produjo 2,961 kg de CP por hectárea y año.

Brachiaria humidicola (P.I. 299497) fue el mejor productor de GF en el corte de 45 días con 160,459 kg/ha y año, mientras que el Pará tuvo el contenido en DM más alto, 22.5\%. De igual forma, el pasto Pará produjo la cantidad más alta de DF: $31,338 \mathrm{~kg} /$ ha y año, y $B$. humidicola (P.I. 299497) el contenido en CP más alto, 3,787 kg/ha y año.

El pasto más productor de GF en el corte de 60 días fue B. humidicola (P.I. 299497) con 146,318 kg/ha y año, mientras que el Pará arrojó el contenido más alto de DF y CP, 36,946 y $3,264 \mathrm{~kg} / \mathrm{ha}$ y año, respectivamente.

Según se alargó el intervalo de corte, la producción media de GF y DF aumentó. Por otro lado, el contenido en DM fue similar a los 30 y 45 días, pero aumentó en el corte de 60 días. La producción media de CP aumentó de 2,651 en el corte de 30 días a 2,912 kg/ha y año en el corte de 45 días. La producción media de CP disminuyó levemente a $2,803 \mathrm{~kg} / \mathrm{ha}$ y año en el corte de 60 días. 
La producción de DF y CP de los pastos B. humidicola (P.I. 299497), Pará, Signal y otras, fue excelente y compara favorablemente con las mejores yerbas forrajeras cultivadas en Puerto Rico.

\section{LITERATURE CITED}

1. Bogdan, A. V., 1977. In Tropical Pastures and Fodder Plants (Grasses and Legumes), D. Rhind, Ed, p. 54-64, Longmans, London.

2. Caro-Costas, R., Vicente-Chandler, J., and Figarella, J., 1965. Productivity of intensively managed pastures of five grasses on steep slopes in the humid mountains of Puerto Rico, J. Agri. Univ. P. R. 49 (1): 99-111.

3. Loch, D. S., 1977. Brachiarai decumbens (Signal grass), A review with particular reference to Australia, Trop. Grassld. 11 (2): 141-57.

4. Rivera-Brenes, L., Rodríguez-Cabrera, A., and Cestero, H., 1967. Comparison of Giant Pangola, Signal Grass, and Common Pangola as pasture crops in the mountain region. of Puerto Rico, J. Agri. Univ. P. R. 51 (3): 193-200.

5. Sotomayor-Ríos, A., Acosta Matienzo, A., and Vélez-Fortuño, J., 1973. Evaluation of seven forage grasses at two cutting stages, J. Agri. Univ. P. R. 57 (3): 173-185.

6. - Rodríguez-García, J., and Silva, S., 1974. Yield comparison of four forage grasses at two cutting heights and three harvest intervals, J. Agri. Univ. P. R. 58 (1): 26-36.

7. —, Vélez-Fortuño, J., Woodbury, R., Schertz, K. F., and Sierra-Bracero, A., 1960. Description and cytology of a form of Signal grass (Brachiaria brizantha Stapf.) and its agronomic behavior compared to Guinea grass (Panicum maximum Jacq.), J. Agri. Univ, P. R. 44 (4): 208-20.

8. -Vélez-Santiago, J., Torres-Rivera, S., and Silva, S., 1976. Effect of three harvest intervals on yield and composition of nineteen forage grasses in the humid region of Puerto Rico, J. Agri. Univ. P. R. 60 (3): 294-309.

9. Vicente-Chandler, J., Caro-Costas, R., Abruña, F., and Rodríguez, J. A., 1972. Effect of two cutting heights, four harvest intervals and five nitrogen rates on yield and composition of Congo grass under humid tropical conditions, J. Agri. Univ. P. R. 56 (3): 280-291.

10. Whitney, A. S., Vélez-Ramos, A., and Sotomayor-Ríos, A., 1973. Chemical control of Paragrass (Brachiaria mutica (Forsk.) Stapf.) in a humid upland area, J. Agri. Univ. P. R. 57 (2): 129-35. 